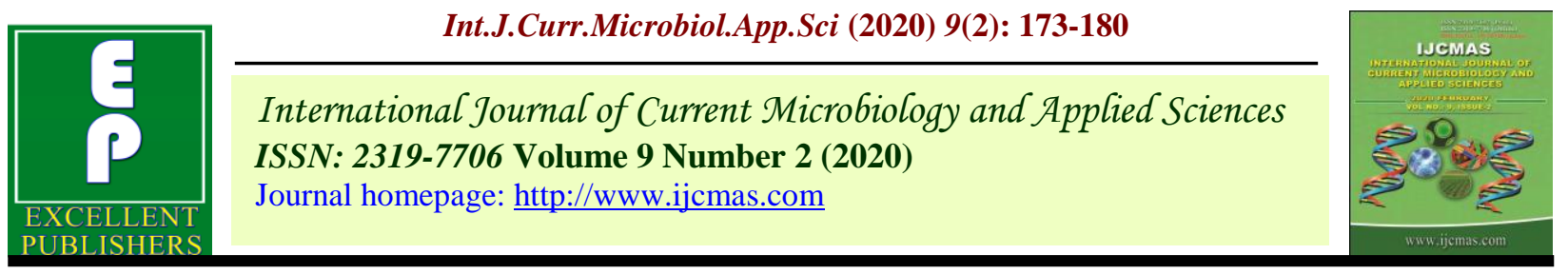

Original Research Article

https://doi.org/10.20546/ijcmas.2020.902.021

\title{
Assessment the Cost and Return in Marine Fish Production in Gujarat, India
}

\author{
Hemant Sharma*, S. S. Kalamkar and M. N. Swain \\ Agro Economic Research Centre, Sardar Patel University, Vallabhvidyanagar, \\ Anand, Gujarat, India \\ *Corresponding author
}

Keywords

Fishery sector, Production, Cost, Marine

Article Info

Accepted:

05 January 2020

Available Online:

10 February 2020

\section{A B S T R A C T}

The aim of the study was to examine the Cost and Return in Marine Fish Production in Gujarat. The primary data were collected from three fishing harbours i.e. Veraval,Porbandar and Mangrol of Gujarat. Every Year, around 13-14 trips were made with around 7 persons on board. On an average, around 14 tonnes fish per trip was caught in selected harbors. The maximum fish was landed at Veraval harbor by selected fishermen, i.e. 14.39 tonnes/trip and the lowest was in Porbandar (12.58 tonnes/trip). The highest cost was incurred by the respondents from Veraval harbor (Rs. 29.62 lakh) while the lowest cost was recorded by respondents from Porbandar harbor (Rs. 22.44 lakh in year) overall Rs. 2.45 crore and Rs. 2.20 crore Gross and net return received in a year by Fisherman. It has been observed that the production of marine fish can be increased by improving the fishing equipments and should be removed or minimized troubles and constraints which are recognized in marine fishing. The dredging problem i.e. loading and unloading of fish due to non-navigable depth near sea shore has been faced by fishermen and therefore harbors dredging needs to be carried out regularly. The prices of fish generally go down sharply during the rainy season (October to December), and for that reason marketing as well as processing activities require to be make stronger by the government.

\section{Introduction}

The fisheries and aquaculture in India are vibrant economic activities, and have been one of the fastest growing food production systems during the last three decades. Their significance and contribution towards agricultural (4.75 per cent GDP in 2012-13 at current prices) and national economies (0.83 percent to national GDP in 2012-13 at current 
prices), livelihood and nutritional security, employment generation (14.49 million people) and foreign exchange earnings (over Rs. 33441 crores in 2014-15) have been enormous though understated so far. Out of the total fish production in India, about 65 percent production is from resources inland and remaining 35 percent from marine sources. Marine fisheries make up a precious resource of food and employment and a net contributor to the balance of payment. Marine fisheries have progressively increased by nearly six times during the last five decades period. The estimated marine resources potential of the Indian Exclusive Economic Zone (EEZ) is 4.24 million metric tonnes at the present exploitation rate. The country has a long coastline of $8118 \mathrm{~km}$ and equally large areas under estuaries, backwaters, lagoons, etc. helpful for increasing capture as well as way of life fisheries. With the declaration of the EEZ in 1977, an area of 2.02 million sq $\mathrm{km}$. (comprising of 0.86 million sq. $\mathrm{km}$ on the west coast, 0.56 million sq. $\mathrm{km}$ on the east coast and 0.60 sq.km around the Andaman \& Nicobar Islands) was protected for fisheries. The East Coast covers four states and two Union Territories (West Bengal, Odisha, Andhra Pradesh, Tamil Nadu, Pondicherry and Andaman \& Nicobar Islands) and the West Coast covers five states and two Union Territories (Gujarat, Daman \& Diu, Maharashtra, Goa, Karnataka, Kerala, and Lakshadweep). The maximum length of coast line $(1912 \mathrm{~km})$ is from Andaman \& Nicobar Island followed by Gujarat $(1600 \mathrm{~km})$ (see, Table 1). Thus, Gujarat state accounts for about one fifth of length of coast line of our country. In India, fish is the major source of protein for over one-third of the population especially for the rural poor in coastal areas. About 35 per cent of Indian population is fish eaters and the per capita consumption is 9.8 $\mathrm{kg}$ whereas the recommended intake is $13 \mathrm{~kg}$ (Srinath et al., 2008; GOI, 2011). The marine fish production has also been stagnating over recent years (CMFRI, 2004). As per FAO, the post harvest loss in world fisheries is 10 per cent. Post-harvest Food Loss (PHL) in general is defined as the measurable qualitative and quantitative loss along the supply chain, starting at the time of harvest till its consumption or other end uses (De Lucia and Assennato, 1994; Hodges, Buzby and Bennett, 2011). Though the fishery sector has transformed in terms of its nature and significance, there are challenges yet to be addressed but reducing or if possible, eliminating economic losses of fisheries due to insufficient post-harvest infrastructure (PHI) services is one of the most significant of them. Being a highly perishable commodity, fish requires proper landing facilities, processing, storage, transport and distribution facilities running through the entire supply chain from capture to consumer.

\section{Materials and Methods}

As mentioned earlier, three harbours of Gujarat namely 1) Porbandar 2) Veraval and 3) Mangrol were selected for the study. For studying the economics of production of fish in Gujarat, 20 fishermen were selected as sample from each selected harbour. Thus, overall 60 sample respondents were personally interviewed for data collection. This Study deals with the status of fish production, fishing activities and Cost and Returns in Marine fisheries sector. There are seven independent variables for the study: Total Trip, Trip duration, Fuel cost, Ice cost, Crew cost, Food cost incurred for crew (fishermen) and Maintenance and Miscellaneous for finding one dependent variable fish catch revenue.

Profitability rations such as Benefit-Cost Ratio of Marine Fish Production. BCR = TR/TC Where; BCR = Benefit Cost Ratio TR $=$ Total Revenue $\mathrm{TC}=$ Total Cost 


\section{Details of fishing crafts (boats) and fishing instruments}

The details on different fishing crafts and fishing instruments available with selected respondents are presented in Tables 1. It can be seen from these tables that high concentration of motorized crafts/boats was observed with selected respondents. On an average of both categories, per household had 2.08 motorised crafts and 0.23 traditional crafts. Across the harbors, Mangrol respondents had highest number of crafts (3.15) followed by Veraval (2.20) and the lowest was in Porbandar (1.60). The variety of fishing device used varies by nature of fishing operation and intention species. Trawlers and Gill net are commonly used in family fishing as they are considered as relatively low cost gear situated for catching many fish species. On an average, every household had 7.32 trawlers and 2.98 gill netters. Besides every household possesses other instruments such as purse seine and cast nut (4.32), deep sea trawlers (0.75) and very few households had long lines tuna, squid jigging and shore seining. Across harbors, the highest number of trawelers per households was observed in Veraval, while Mangrol respondents had the highest number of gill netters and other instruments/hh.

\section{Results and Discussion}

\section{Details of fishing activities}

The oceanic fisheries activity take advantage of a large number of species using special crafts and kit in different localities Trawl and purse nets aroused in these boats and were operated by a larger group consisting of more than 6 fishermen on a single boat. The details on hourbour wise fishing activities by selected fishermen are presented in Tables 2 . It can be seen from these tables that on an average, the fishing days in a year were estimated to be 197 days, (ranges between 194-197 days in year). The highest fishing days were recorded in October-December period, which may be due to 90 days (from $15^{\text {th }}$ of May to $15^{\text {th }}$ of August) fishing ban during this season.

In view of fisheries situation that exists in west coast of India, temporal restrictions, i.e. seasonal closure of fishing is implemented separately by each State administration to deal with the fishery assets. Every year, around 14-15 trips were made (around 13-15 days per trip) with around 7 persons on board. In case of Porbandar and Veraval, all trips were multidays fishing (ranges between 12-18 days), while 90 percent of trips of Mangrol respondents were multi-days and reaming 10 percent were a day fishing trips. The use of conventional crafts has been observed in Veraval and Mangrol marina.

\section{Details of fish caught $\&$ sold}

The harbourwise details on fish catch and sold is presented in Tables 3. An around 13.20 tons fish per trip was caught in which around 85 percent percent fish was of Grade I and remaining was grade II(low grade) in study area. The maximum fish was landed at Veraval harbor by selected boat owners and fishermen, i.e. 14.39 tonnes/trip and the lowest was in Porbandar (12.58 tonnes/trip).

Fish catch depends entirely on the size of the boats, types of fishing gear, types of nets and also the number of times the fishermen go to the sea in a day.

The sale pattern of fish landed indicates that at overall level, about 94 percent of total fish was sold, of which around 37 percent each was sold to exporter, around 29 percent to wholesaler and contractor and remaining was sold to retailer. 


\section{Time and cost incurred in fishing activity}

The details on time and cost incurred in fishing activity per trip are presented in Tables 4. It can be seen from these tables that at overall level, about 15 fishing nets/instruments were taken during each fishing trip which was made around 126 nautical miles away from the sea shore. The approximate time taken for fishing was around 141 hours while time taken for landing/unloading fish was 31.6 hours by machine and 3.2 hours by manually. The time taken for fishing per trip was higher in case of boat owner (153.8 hours) than fishermen (128.1 hours), while time taken of loading/uploading was less in case of fishermen that of boat owner. On an average 2688 liters of diesel fuel was taken on board/trip, out of which 88 percent fuel was used. The infrastructural facilities available on board play an important role in reducing the post harvest losses. The fish hold capacity of fishing vessel was 10.7 tonnes/boat. The average number of ice boxes available were
11.17 having capacity of $480 \mathrm{~kg}$. It is important to note that no fishing boat had insulated box on board. The lifting facilities were available on about 53 percent boats while dragging facility was with remaining ones. The status of fish hold at all three harbors was fresh one. The washing and cleaning facility was available on about 83 percent craft, while 17 percent were not having this facility. Among the various processing facilities, icing facility was available on all fishing crafts of both fishermen and boat owner, having average capacity of about 10 tones. However, no boat had other processing facilities like freezing facility, canning facility, smoking facility, smoking facility and any other facility on board. The sorting of board facility was available on all the crafts used by fishermen and boat owners. Veraval respondents had spent relatively more in grading the fish on board as compared to other two harbor respondents. Thus, icing facility was available on board for all crafts and sorting was done on board by the fishermen.

Table.1 Number of fishing crafts/instruments (tools) with boat per household

\begin{tabular}{|c|c|c|c|c|c|}
\hline \multirow[t]{2}{*}{$\begin{array}{l}\text { Sr. } \\
\text { No. }\end{array}$} & \multirow[t]{2}{*}{ Type of Fishing Crafts } & \multicolumn{4}{|c|}{$\begin{array}{l}\text { Number of Fishing Crafts and vessels / } \\
\text { household }\end{array}$} \\
\hline & & Porbandar & Veraval & Mangrol & Overall \\
\hline \multirow[t]{5}{*}{$\mathbf{A}$} & Fishing Crafts/Boats & & & & \\
\hline & a) Traditional Crafts/Boats & 0.00 & 0.14 & 0.55 & 0.23 \\
\hline & b) Motorized Crafts/Boats & 1.60 & 2.05 & 2.60 & 2.08 \\
\hline & c) Mechanized Boats/Boats & 0.00 & 0.00 & 0.00 & 0.00 \\
\hline & Total & 1.60 & 2.20 & 3.15 & 2.32 \\
\hline \multirow[t]{8}{*}{ B } & Fishing Instruments/tools & & & & \\
\hline & a) Trawlers & 7.90 & 8.35 & 5.70 & 7.32 \\
\hline & b) Gill netters & 0.30 & 4.30 & 4.35 & 2.98 \\
\hline & c) Deep Sea Trawlers & 0.55 & 0.80 & 0.90 & 0.75 \\
\hline & d) Long liners for Tuna & 0.00 & 0.00 & 0.15 & 0.05 \\
\hline & e) Squid Jigging & 0.00 & 0.00 & 0.20 & 0.07 \\
\hline & f) Shore seining & 0.00 & 0.00 & 0.5 & 0.17 \\
\hline & $\begin{array}{l}\text { g) Others (Purse Seine \&Cast } \\
\text { nut ) }\end{array}$ & 2.70 & 4.35 & 5.90 & 4.32 \\
\hline
\end{tabular}

Source: Field Survey Data. 
Table.2 Harbourwise details of fishing activities

\begin{tabular}{|c|c|c|c|c|c|c|}
\hline \multirow{2}{*}{$\begin{array}{l}\text { Sr. } \\
\text { No. }\end{array}$} & \multirow{2}{*}{ Particulars } & \multirow[t]{2}{*}{ Unit } & \multicolumn{4}{|c|}{ Details of Fishing activities- ALL } \\
\hline & & & Porbandar & Veraval & Mangrol & Av. \\
\hline $\mathbf{A}$ & Fishing days per year & Av no. & 194 & 199 & 197 & 197 \\
\hline B & Fishing trips in year & Av no. & 15 & 13 & 14 & 14 \\
\hline $\mathbf{C}$ & Fishing trips by type of fishing craft & Av no. & & & & \\
\hline & a)Traditional & & 0 & 1 & 1 & 0.66 \\
\hline & b) Motorized & & 15 & 12 & 13 & 13.3 \\
\hline & c) Mechanized & & 0 & 0 & 0 & 0 \\
\hline & d)Others & & 0 & 0 & 0 & 0 \\
\hline D & Fishing Vessel & $\%$. & & & & \\
\hline & a) Day fishing & & 0 & 0 & 10 & 3.33 \\
\hline & b) Multi Day Fishing & & 100 & 100 & 90 & 96.67 \\
\hline $\mathbf{E}$ & Days of fishing per trip & $\begin{array}{l}\text { Av } \\
\text { no. }\end{array}$ & 12.9 & 15.3 & 14.1 & 14.1 \\
\hline $\mathbf{F}$ & Fisherman on-board & $\begin{array}{l}\text { Av } \\
\text { no. }\end{array}$ & 6.7 & 8 & 6.9 & 7.2 \\
\hline
\end{tabular}

Source: Field Survey Data.

Table.3 Harbourwise details of fish caught \& sold

\begin{tabular}{|c|c|c|c|c|c|c|c|c|c|}
\hline \multirow{3}{*}{$\begin{array}{l}\text { Sr. } \\
\text { No. } \\
\text { A) }\end{array}$} & \multirow{3}{*}{$\begin{array}{c}\text { Harbour } \\
\text { Fish landed per trip }\end{array}$} & \multicolumn{8}{|c|}{ Details of Fish Caught \& Sold } \\
\hline & & \multicolumn{2}{|c|}{ Porbandar } & \multicolumn{2}{|c|}{ Veraval } & \multicolumn{2}{|c|}{ Mangrol } & \multicolumn{2}{|c|}{ Overall } \\
\hline & & 12.58 & 100.0 & 14.39 & 100.0 & 12.63 & 100.0 & 13.20 & 100.0 \\
\hline & a) Grade I (high value) & 9.40 & 74.8 & 11.05 & 76.8 & 10.10 & 80.0 & 10.18 & 77.2 \\
\hline & b) Grade II (low value) & 3.18 & 25.2 & 3.34 & 23.2 & 2.53 & 20.0 & 3.01 & 22.8 \\
\hline \multirow[t]{5}{*}{ B) } & Fish Sold & 11.80 & 93.9 & 13.32 & 92.5 & 11.86 & 93.9 & 12.33 & 93.4 \\
\hline & a)Exporter & 4.05 & 34.3 & 6.66 & 50.0 & 2.92 & 24.6 & 4.54 & 36.8 \\
\hline & b)Wholesaler & 3.31 & 28.0 & 3.70 & 27.8 & 3.86 & 32.5 & 3.62 & 29.4 \\
\hline & c)Retailer & 0.38 & 3.2 & 0.46 & 3.4 & 0.66 & 5.6 & 0.50 & 4.0 \\
\hline & d)Contractor & 4.07 & 34.5 & 2.51 & 18.8 & 4.42 & 37.3 & 3.67 & 29.7 \\
\hline C) & Fish waste/fish dumped & 0.33 & 2.6 & 0.48 & 3.4 & 0.36 & 2.9 & 0.39 & 3.0 \\
\hline D) & Fish use to dry/fish meal & 0.44 & 3.5 & 0.59 & 4.1 & 0.41 & 3.2 & 0.48 & 3.6 \\
\hline
\end{tabular}

Source: Field Survey Data. 
Table.4 Details on time and cost incurred in fishing activity

\begin{tabular}{|c|c|c|c|c|c|c|}
\hline $\mathbf{S} \mathbf{N}$ & Operational expenses & Unit & Porbandar & Veraval & Mangrol & Total \\
\hline 1 & $\begin{array}{l}\text { Fishing nets/instruments } \\
\text { taken per fishing trip }\end{array}$ & Av. No. & 13.4 & 16.8 & 15.1 & 15.1 \\
\hline 2 & $\begin{array}{l}\text { Distance of the fishing } \\
\text { ground from the shore }\end{array}$ & $\begin{array}{l}\text { Nautical } \\
\text { miles }\end{array}$ & 88.2 & 109.0 & 180.9 & 126.0 \\
\hline 3 & $\begin{array}{l}\text { Approximate time taken } \\
\text { for fishing }\end{array}$ & hrs. & 130.3 & 118.5 & 174.1 & 141.0 \\
\hline \multirow[t]{2}{*}{4} & $\begin{array}{l}\text { Time taken for } \\
\text { landing/unloading }\end{array}$ & hrs. & 30.1 & 43 & 31.3 & 34.8 \\
\hline & Total Trip /Year & & 15.00 & 13.00 & 14.00 & 14.00 \\
\hline $\mathbf{A}$ & Operational Expenditure & \multirow{7}{*}{$\begin{array}{c}\text { Rs./total } \\
\text { trip in } \\
\text { year }\end{array}$} & & & & \\
\hline I. & Exp. on Food and Water & & 138000 & 198900 & 154000 & 163633 \\
\hline II. & Fuel Cost & & 1280790 & 1971606 & 1656690 & 1636362 \\
\hline III. & Hired labour cost & & 577500 & 624000 & 672000 & 624500 \\
\hline IV. & Ice cost & & 82500 & 106600 & 95900 & 95000 \\
\hline \multirow[t]{2}{*}{ V. } & Any other expenditure & & 165825 & 191633 & 177380 & 178279 \\
\hline & Total Cost & & 2244615 & 2962739 & 2475970 & 2561108 \\
\hline B & Income & & & & & \\
\hline \multirow[t]{3}{*}{$\mathbf{a}$} & Fish landed per trip & \multirow{8}{*}{$\begin{array}{c}\text { Rs. In } \\
\text { crore /total } \\
\text { trip in } \\
\text { year }\end{array}$} & 2.48 & 2.51 & 2.50 & 2.49 \\
\hline & a) Grade I (high value) & & 2.12 & 2.16 & 2.26 & 2.18 \\
\hline & b) Grade II (low value) & & 0.36 & 0.35 & 0.23 & 0.31 \\
\hline \multirow[t]{5}{*}{ b } & Fish use to dry/fish meal & & 0.02 & 0.03 & 0.02 & 0.02 \\
\hline & Total Income & & 0.09 & 0.06 & 0.09 & 0.06 \\
\hline & Fish waste/fish dumped & & 2.50 & 2.53 & 2.51 & 2.52 \\
\hline & Gross Return & & 2.41 & 2.48 & 2.42 & 2.46 \\
\hline & Net Return & & 2.19 & 2.18 & 2.18 & 2.20 \\
\hline C) & B:C Ratio & & 9.75 & 7.36 & 8.78 & 8.59 \\
\hline
\end{tabular}

Note: 1 Nautical mile $=1.852 \mathrm{~km}$.

The total operational expenditure incurred has been estimated to be Rs. 25.61 lakh comprised of expenditure on food and water, fuel cost, ice cost, hired labour and other miscellaneous items. There was huge difference in cost incurred by respondents of three selected harbors. The highest cost was incurred by the respondents from Veraval harbor (Rs. 29.62 lakh) while the lowest cost was recorded by respondents from Porbandar harbor (Rs. 22.44 lakh in year). The high cost per trip at Veraval and Mangrol respondent would be due to longer time taken for fishing.
Around two third of total cost was incurred on fuel only, followed by about one fifth of total cost on hired human labour for fishing activity. Thus, these two costs put together accounted for about 84 percent of total cost. The expenses on food with water and miscellaneous expenditure accounted for around 7 percent each to total cost. The total quantity of ice used by fisherman on an average was $4725 \mathrm{~kg}$ per trip. The harbor wise Gross and net return in marine fish production in the above table. It can be seen that the overall Rs. 2.45 crore and Rs. 2.20 crore 
Gross and net return received in a year by Fisherman. The highest net return was received by the respondents from Porbander harbor (Rs. 2.18 crore) due the lowest cost (Rs. 24.44 lakh in year) was recorded by respondents from Porbander harbor.

It is concluded that the aim of the study was to examine the Cost and Return in Marine Fish Production in Gujarat. The primary data were collected from three fishing harbours i.e. Veraval, Porbandar and Mangrol of Gujarat. Every Year, around 13-14 trips were made with around 7 persons on board. On an average, around 14 tonnes fish per trip was caught in selected harbors. The maximum fish was landed at Veraval harbor by selected fishermen, i.e. 14.39 tonnes/trip and the lowest was in Porbandar (12.58 tonnes/trip). The highest cost was incurred by the respondents from Veraval harbor (Rs. 29.62 lakh) while the lowest cost was recorded by respondents from Porbandar harbor (Rs. 22.44 lakh in year) overall Rs. 2.45 crore and Rs. 2.20 crore Gross and net return received in a year by Fisherman. It has been observed that the production of marine fish can be increased by improving the fishing equipments and should be removed or minimized troubles and constraints which are recognized in marine fishing.

\section{Policy Suggestions}

The fishermen should be provided training on proper handling and transport of fishes by the government and cooperative organization.

The dredging problem i.e. loading and unloading of fish due to non-navigable depth near sea shore has been faced by fishermen and therefore harbors dredging needs to be carried out regularly.

It was reported that the prices of fish generally go down sharply during the rainy season (October to December), and for that reason marketing as well as processing activities require to be make stronger by the government.

\section{References}

CMFRI (2004), Annual Report 2003-04, Central Marine Fisheries Research Institute, Cochin.

De Lucia, M. and D. Assennato (1994), "Agricultural Engineering in Development: Post-harvest Operations and Management of Foodgrains", FAO Agricultural Services Bulletin No. 93.

FAO (1981), "Prevention of Losses in Cured Fish", Fisheries Technical Paper No. 219, Food and Agricultural Organization of the United Nations, FAO, Rome0 2003.

FAO (1995), Code of Conduct for Responsible Fisheries, Food and Agriculture Organization of the United Nations, Rome.

FAO (2014), National Aquaculture Sector Overview. India, National Aquaculture Sector Overview Fact Sheets. Text by Ayyappan, S. In: FAO Fisheries and Aquaculture Department [online]. Rome. Updated 4 April 2014. [Cited 28 February 2016, http://www.fao.org/fishery/countrysecto r/naso_india/en)

FAO (2014a), The State of World Fisheries and Aquaculture-Opportunities and challenges, Food and Agriculture Organization of The United Nations, Rome (http://www.fao.org/3/ai3720e.pdf).

GOG (2013), Fisheries Statistics of Gujarat 2012-13, Commissioner of Fisheries, Government of Gujarat, Gandhinagar.

GOG (2015), Fisheries Statistics of Gujarat 2014-15, Commissioner of Fisheries, Government of Gujarat, Gandhinagar.

GOI (2011), Report of the Working Group for 
Development and Management of Fisheries and Aquaculture for the XII Five Plan: 2012-17, Planning Commission, Government of India, January.

GOI (2011a), Manual on Fishery Statistics, Ministry of Statistics and Programme Implementation, Central Statistics Office, Government of India (http://mospi.nic.in/Mospi_New/upload/ Manual_Fishery_Statistics_2dec11.pdf). GOI (2014), Handbook on Fisheries Statistics 2014, Department of Animal Husbandry, Dairying and Fisheries, Ministry of Agriculture Government of India, Krishi Bhavan, New Delhi

Hodges, R.J., J.C. Buzby, and B. Bennett (2011), "Postharvest Losses and Waste in Developed and Less Developed Countries: Opportunities to Improve Resource Use", Journal of Agricultural Science, 149, pp. 37-45.

Srinath, Krishna; V. Radhakrishnan Nair;
G.R. Unnithan; Nikita Gopal; H. V. L. Bathla and Ahamad Tauqueer (2008), "Post-harvest Losses in Marine Fisheries", Fishery Technology, Vol. 44, No. 1, pp 117-120.

http://pib.nic.in/newsite/PrintRelease.aspx?rel $\mathrm{id}=131762$

www.mpeda.gov.in The Marine Products Export Development Authority

http://www.fao.org/docrep/005/v9878e/v9878 e00.htm

http://www.fao.org/docrep/008/ae934e/ae934 e04.htm

http://cmfri.org.in/survey/downloads.php http://www.fao.org/3/a-i3720e.pdf www.indianstat.com http://mospi.nic.in/Mospi_New/upload/Manu al_Fishery_Statistics_2dec11.pdf https://cof.gujarat.gov.in/Images/commissione roffisheries/pdf/Fisheries-Glance-1213.pdf

http://dahd.nic.in/

\section{How to cite this article:}

Hemant Sharma, S. S. Kalamkar and Swain, M. N. 2020. Assessment the Cost and Return in Marine Fish Production in Gujarat, India. Int.J.Curr.Microbiol.App.Sci. 9(02): 173-180. doi: https://doi.org/10.20546/ijcmas.2020.902.021 